\title{
A THEORY OF GENRE: ROMANCE, REALISM, AND MORAL REALITY
}

\author{
ROBERT C. POST \\ Washington, D. C.
}

IN HER OWN UNASSUMING BUT PENETRATING WAY, VIRGINIA WOOLF strongly advised authors "to live in the presence of reality." Since "philosophic words, if one has not been educated at a university, are apt to play one false," Woolf could not define precisely what she meant by "reality." It was, she said, "something very erratic, very undependable - now to be found in a dusty road, now in a scrap of newspaper in the street, now in a daffodil in the sun." She could describe reality only by noting that whatever it "touches, it fixes and makes permanent"; reality is what appears when the world is "bared of its covering and given an intenser life." Reality is "invigorating." The writer's business, Woolf concluded, was to find this reality, to "collect it and communicate it to the rest of us.", 1

Woolf's concept of "reality" is complex, and its implications are worth examination. It differs considerably from the idea of reality which is prevalent among literary historians, and which is exemplified by Rene Wellek's definition of realism as "the objective representation of contemporary social reality." For Wellek reality is not, as for Woolf, a normative concept. It is instead a collection of facts which exist independently in the world and await reproduction by the writer. This same concept of reality underlies Jose Ortega y Gasset's distinction between realist and modernist art: comparing the work of art to a window pane, he said that works of realism look through the glass and make it invisible, whereas modernist works focus instead on the glass itself and see only a confused blur of color and form. ${ }^{2}$

That sophisticated literary historians should hold this view of reality is somewhat startling, since philosophy long ago rejected the belief that

\footnotetext{
${ }^{1}$ Woolf, A Room of One's Own (New York: Harcourt, 1957), 14.

${ }^{2}$ Wellek, Concepts of Criticism (New Haven: Yale Univ. Press, 1963), 240; Ortega y Gasset, The Dehumanization of Art (Princeton: Princeton Univ. Press, 1968), 10.
} 
reality exists "out there" beyond the glass, waiting to be copied. We can say with some assurance that the perception of reality is instead a creative process. In the words of John Dewey: "We do not have externally given to us some fixed conception of reality which we can compare with our ideas, and thereby see how much agreement with reality the latter have. Reality, like everything else that has meaning, is a function of our ideas." Not only is reality cognitively constructed, it is, as our sociologists tell us, "socially constructed." A society's reality is a cultural artifact; it is a "social achievement, directed by the community of needs and interests and fostered in the interests of cooperation.",3

The question of reality is important for the literary historian because it is commonly agreed that every novel presents an image of the world in which its characters exist and interact. ${ }^{4}$ The naive philosophical realism that has unfortunately characterized literary history, however, has led to two alternative interpretations of this fictive image of the world. Either, in the case of literary realism, this fictive image is understood to be an accurate reproduction of "objective" reality, or, in the case of other literary forms, this fictive image is detached from "objective" reality and explained in terms of the conventions of literary composition. ${ }^{5}$ Naive philosophical realism thus virtually compels the literary historian to interpret changes in the literary representation of reality in terms of the transformation of purely aesthetic priorities, and it leads him to underestimate the possibility that these changes may in fact be caused by a larger cultural evolution in the apprehension of reality itself.

The particular manner in which a novel represents reality is, however, as Virginia Woolf's remarks amply illustrate, difficult to specify. The novel's world is often fanciful or imaginary, and what reality the novel does portray is highly selective. At first blush, therefore, it would seem to follow that literary historians are correct, and that the reality represented by the novel is merely a literary construct, more or less unrelated to the actual world of the surrounding culture.

But this conclusion is a non-sequitur. What has been demonstrated is only that the fictive world of the novel is, in some respects, different from

\footnotetext{
${ }^{3}$ Dewey, "Knowledge as Idealization," in his Philosophy, Psychology and Social Practice, ed. Joseph Ratner (New York: G. P. Putnam's Sons, 1965), 159; Peter L. Berger and Thomas Luckmann, The Social Construction of Reality (Garden City, N.Y.: Doubleday, 1968), 1; C. I. Lewis, Mind and the World Order (New York: Dover, 1956), 116.

${ }^{4}$ This insight is common to such otherwise disparate critics as Georg Lukacs, The Theory of the Novel, trans. Anna Bostock (Cambridge: MIT Press, 1971), 60; and Frank Kermode, The Sense of an Ending (London: Oxford Univ. Press, 1967), 140.

${ }^{5}$ Even the pathbreaking work of Erich Auerbach, Mimesis: The Representation of Reality in Western Literature (Garden City, N.Y.: Doubleday, 1958), 107, conceived the differing portrayals of reality in Western literature to be primarily a matter of various literary techniques in the representation of "the objective world of reality."
} 
the world we experience in everyday life. A deeper analysis, however, reveals that the artistic success of a novel depends precisely upon the similarity of its fictive world, in certain other respects, to the ordinary reality we inhabit. The reality created by a novel is a very special kind of reality, whose nature is determined by the cultural functions which the novel performs. These cultural functions are manifested in the aesthetic criteria by which the novel is judged. A criterion of major and unvarying importance is that the quality of a novel depends upon the richness and depth with which it illuminates the possibilities of human value and significance. But these possibilities only have meaning if they are perceived by the audience to be real, not merely literary constructs. The aesthetic criterion will thus be satisfied only if the novel's audience believes that, given the nature of the actual world they experience, the potential for the realization of these possibilities truly exists. The novel, as a contemporary author states, is "an affirmation of what ought to be and what, in the artist's devout opinion, is, whether or not it can be reached from where we are." 6

The novel, in other words, presents the reality of human meaning, which I shall call "moral reality." This is the complex form of reality which Virginia Woolf urged writers to find, collect, and communicate. Moral reality is a cultural artifact which, like all such artifacts, evolves in time. Moreover, as Woolf's example illustrates, moral reality does not exist in some abstract ethical realm. It is instead predicated upon specific and demonstrable assumptions about the nature of the world, about the way in which individuals, society, or the natural universe must exist in order for human meaning to be possible. For a novel to succeed aesthetically, these assumptions must be recognized by its readers as descriptive of the reality they inhabit, and thus no matter how fancifully a novel may otherwise portray the world, it cannot violate these assumptions without simultaneously breaching the aesthetic criterion that requires the novel seriously to explore the possibilities of human value.

Once this aesthetic understanding of the novel is accepted, and once an ingenuous philosophical realism is safely laid to rest, the concept of moral reality becomes a legitimate and important analytic tool for the literary historian. In this article I will explore its usefulness in providing a foundation for a theory of genre in the novel. The concept of moral reality provides such a foundation because the novel is, as R. P. Blackmur has stated, "a theoretic form for our experience of life," 7 and moral reality establishes the predicates for that form. It not only thematically defines

\footnotetext{
${ }^{6}$ John Gardner, On Moral Fiction (New York: Basic Books, 1977), 162.

${ }^{7}$ Blackmur, "Between the Numen and the Moha," The Lion and The Honeycomb: Essays in Solicitude and Critique (New York: Harcourt, 1955), 303.
} 
relevant aspirations, and, by implication, pertinent temptations, but it also entails specific assumptions about the nature of the human, social, or natural materials out of which that form will emerge. In this sense moral reality enables the novelist to create coherence out of the "buzzing, blooming confusion" of his experience. Most literary historians view the novel, as does Lionel Trilling, as "a perpetual quest for reality, the field of its research being always the social world, the material of its analysis being always manners as the indication of the direction of man's soul." 8 The concept of moral reality, however, points in the opposite direction: it is only because a novel presupposes a reality, a conception of manners, soul, and society, that it can exist at all. The moral reality assumed by the novelist will thus deeply affect the literary presentation of his experience; it will influence such various aesthetic concerns as methods of characterization, rendition of dialogue and action, treatment of natural and social settings, and organization of narrative presentation. ${ }^{9}$

Novels which share a common moral reality will therefore also share common aesthetic attributes. We classify these family resemblances as genres. In nineteenth-century American fiction, for example, it is commonly recognized that the romance and the realist novel represent two such genres. In this article I will analyze an example of each of these genres and demonstrate that the characteristic aesthetic attributes of each can be traced back to a systematic apprehension of moral reality. The usefulness of this approach can best be illustrated by contrasting it to the usual manner in which historians of American literature have discussed these two genres.

The traditional framework of analysis has been to contrast the romance to the realist novel, and to conclude that, while the latter "objectively" represents reality, the former must be understood in terms of its use of particular literary devices. The naive philosophical realism of this approach is exemplified by Richard Chase, whose The American Novel and Its Tradition is probably the most influential attempt to distinguish the romance from the realist novel. ${ }^{10}$ Chase begins his discussion in what appears to be a promising manner. "The main difference between the novel and the romance," he asserts, "is the way in which they view reality." It soon becomes apparent, however, that what Chase means is

\footnotetext{
${ }^{8}$ Trilling, "Manners, Morals, and the Novel,"' The Liberal Imagination: Essays on Literature and Society (Garden City, N.Y.: Doubleday, 1953), 205.

${ }^{9}$ On this point, see Georg Lukacs, Realism in our Time: Literature and the Class Struggle, trans. John and Necke Mander (New York: Harper, 1971), 19.

${ }^{10}$ Chase, The American Novel and Its Tradition (Garden City, N.Y.: Doubleday, 1957), 1-28. For an example of Chase's influence, see Richard H. Brodhead, Hawthorne, Melville, and the Novel (Chicago: Univ. of Chicago Press, 1976), 20-25. There is a good discussion of Chase in David H. Hirsch, Reality and Idea in the Early American Novel (The Hague: Mouton, 1971), 32-49.
} 
that the novel describes objective reality, while the romance does not. Chase claims that the novel "renders reality closely and in comprehensive detail." In the novel, character "is more important than action and plot," and character is realized in its "real complexity of temperament and motive." Characters are "in explicable relation to nature, to each other, to their social class, to their own past." Events in the novel, "will usually be plausible." The reality of the romance, on the other hand, is described in terms that are largely negative. The romance, Chase contends, "feels free to render reality in less volume and detail." It prefers action to character, "and action will be freer in a romance than in a novel, encountering, as it were, less resistance from reality." Romance action will feature "astonishing events" which "are likely to have a symbolic or ideological, rather than a realistic plausibility." Despite the fact that "character may become profoundly involved," characters in the romance are "somewhat abstract and ideal," not "completely related to each other or to society or to the past." In short, "being less committed to the immediate rendition of reality than the novel," the organizing principle of the romance is not objective social reality, but the use of literary devices such as "mythic, allegorical, and symbolistic forms."

Defining the romance in terms of its literary techniques, however, turns out to be vague and imprecise, leading to endless and unproductive debates on such questions as whether The Golden Bowl is truly a romance or a novel. The point, of course, is that the literary themes and techniques identified by Chase are used and employed by a great many more works than those that by consensus constitute examples of the American nineteenth-century romance. The inability systematically to comprehend the aesthetic attributes of the romance has thus led to the widespread and confusing diversity of opinion which now dominates the contemporary critical scene. For Perry Miller, the romance is the connection between character and Nature. F. O. Matthiessen views it as primarily a concern for "the life within the life," whereas for Terrence Martin it has a certain kind of improbability. Joel Porte, on the other hand, considers the romance to be a form of stylized art that attempts to explore the darker sides of the self. Daniel Hoffman believes the romance depends upon "folklore, myth, and ritual," while Nicolaus Mills sees no significant distinction at all between the romance and the realist novel. ${ }^{11}$

\footnotetext{
${ }^{11}$ Miller, "Romance and the Novel," Nature's Nation (Cambridge: Belknap Press, 1967), 260; Matthiessen, American Renaissance: Art and Expression in the Age of Emerson and Whitman (London: Oxford Univ. Press, 1968), 271; Martin, The Instructed Vision: Scottish Commonsense Philosophy and the Origins of American Fiction (Bloomington: Indiana Univ. Press, 1961), 58; Porte, The Romance in America: Studies in Cooper, Poe, Hawthorne, Melville, and James (Middletown: Wesleyan Univ. Press, 1961), 26; Hoffman, Form and Fable in American Fiction (New York: Oxford Univ. Press, 1961), 26; Mills, American and English Fiction in the Nineteenth Century: An Antigenre Critique and Comparison (Bloomington: Indiana Univ. Press, 1973), 11-12.
} 
No critic has thus far taken seriously the possibility that the aesthetic characteristics of the romance can be explained with reference to a systematic understanding of moral reality. This is perhaps because, firmly and unconsciously entrenched in our own cultural reality, we see in the moral reality of the past only the unreal world of myths and symbols. Our inability to discern the moral reality of romance, in short, is but the other side of our uncritical acceptance of the "objective" reality of realism. In the following two sections of this article, I hope to unsettle both these prejudices by discussing two short stories, one in the genre of the romance, the other in that of realism. Just as realism is not "the objective representation" of social reality, but is instead a genre whose common aesthetic characteristics derive from a particular understanding of moral reality, so the romance can be defined with reference to a moral reality of precisely analogous logical properties and coherence.

The two short stories I have selected for discussion are "Drowne's Wooden Image" by Nathaniel Hawthorne and "The Real Thing" by Henry James. Both concern the transformation of reality into art, the former in the romance mode, the latter in the realistic. I have chosen them not because they are so very exceptional, but because they are competent and representative examples of their respective genres.

"Drowne's Wooden Image" is the story of a colonial wood carver who specializes in the figureheads of ships. Although he has "no inconsiderable skill of hand" (350), his sculptures appear wooden and mechanical, as does Drowne himself. ${ }^{12}$ Drowne is commissioned by a Captain Hunnewell to carve a figurehead for the brig Cynosure. As is customary with Hawthorne, there is a secret in the matter, and Drowne is observed working mysteriously at nights upon his new commission. The work, an image of an exotic and flirtatious lady, becomes Drowne's masterpiece, acknowledged by the townspeople and by the painter Copley, who serves in the story as a sort of narrative alter ego. In the process of sculpting the work, Drowne turns into "a modern Pygmalion" (353), deeply in love with either the carving or its model. Copley observes Drowne bending over the sculpture "as if he would have embraced it and drawn it to his heart; while, had such a miracle been possible, his countenance expressed passion enough to communicate warmth and sensibility to the lifeless oak" (353). When Captain Hunnewell comes to collect the completed carving, he is accompanied by a lady who is the exact replica of the

${ }^{12}$ All page references to "Drowne's Wooden Image" are from Hawthorne, Mosses from an Old Manse (Boston: Houghton, Mifflin, 1882). 
statue. The town bursts with the speculation that the wooden image has come to life, but Hawthorne is careful to inform us that she is a young Portuguese lady of rank, temporarily and secretly under the protection of Captain Hunnewell.

Marius Bewley, in an excellent analysis of "Drowne's Wooden Image," has uncovered "a metaphysic concerning the nature of reality" in Hawthorne's work. He has found that in Hawthorne reality is associated with an "inner sphere of feeling and sympathy," and is attainable only through the kind of "self-surrender" of which love is an emblem. But in order to make Hawthorne compatible with our own modern sensibilities, Bewley interprets this reality in a purely psychological sense. "Hawthorne's inner sphere of reality is little more than the quiet and pure communion of a human mind and heart with others in love and charity." Bewley thus reads the lesson of the story to be that "[s]elf-surrender in art, no less than in human relationships, is required if one is to enter into and possess inner reality." 13

Bewley's psychological interpretation of Hawthorne's inner reality, however, can at most elucidate why Drowne fulfilled himself in his sculpture. It cannot explain why the carving was itself a success; why, in its presence, the townspeople "felt impelled to remove their hats" (356), and feared as if before something "preternatural" (356). Nor can it explain why the carving should have affected Copley with "speechless astonishment" (353) when "the image was but vague in its outward presentment" (353); or why, when the real Portuguese lady unhinged her fan, the fan in the hand of the carving should have simultaneously broken. We are often tempted to interpret such incidents as evidence merely of that irritating flavor of the miraculous with which Hawthorne felt impelled to season his fiction, and to dismiss them as immature "symbolism" or "allegory." Nothing could be more revealing of our tendency to appropriate the reality of another culture and reinterpret it in light of our own assumptions. And nothing could interfere more seriously with our attempt to recover the moral reality behind Hawthorne's work. For while Hawthorne in his prefaces claimed a certain freedom from "the realities of the moment," and even from "the probable and ordinary course of man's experience," his fiction tells us again and again of his ambition to create a literature "before which the forms and fantasies that conceal the inner idea from the multitude vanish at once and leave the naked reality underneath." 14

${ }^{13}$ Bewley, The Eccentric Design: Form in the Classic American Novel (New York: Columbia Univ. Press, 1959), 23, 127, 132, 174, 138.

${ }^{14}$ Hawthorne, Pref., The House of the Seven Gables (Boston: Houghton, Mifflin, 1883), 13, 15; " The Intelligence Office," in Hawthorne, Mosses from an Old Manse, 379. See Jesse Bier, "Hawthorne on the Romance: His Prefaces Related and Examined," Modern Philology, 53 (1955), 17-24. 
We must suspend the suspicion, then, that Hawthorne's fiction is at times merely an exercise in fantasy, and we must take seriously Hawthorne's perception of a "naked reality." This reality is evidently a source of human value and significance, for as it is perceived and appropriated by Drowne, his moral and spiritual faculties awaken and develop. Hawthorne carefully describes Drowne's development not merely as a psychological transformation, but also as the acquisition of insight. Drowne states that "there has come a light into my mind" (352); he claims that he has been able to produce his magnificent statue because a "wellspring of inward wisdom gushed within me as I wrought upon the oak with my whole strength, and soul, and faith" (355). Drowne, in other words, acquires knowledge, and this knowledge, though "inward," is of something beyond himself.

For Hawthorne, Drowne's awakening as a human being and his growth as an artist are one and the same phenomenon. What was lacking in Drowne's mechanical carvings is also what was missing from his own moral development. Hawthorne tells us that the lifeless carvings

looked as if a living man had there been changed to wood, and that not only the physical, but the intellectual and spiritual part, partook of the stolid transformation. But in not a single instance did it seem as if the wood were imbibing the ethereal essence of humanity. What a wide distinction is here! and how far would the slightest portion of the latter merit have outvalued the utmost of the former (351)!

What Drowne and his productions need is to regain contact with "the ethereal essence of humanity." Hawthorne tells us that this essence does not reside in outward forms; it can be found neither in the correct physical outlines of Drowne's wooden carvings, nor in the "dignified station in the church" (361), which Drowne mechanically fills. It is instead a matter of "that deep quality, be it of soul or intellect, which bestows life upon the lifeless and warmth upon the cold, and which, had it been present, would have made Drowne's wooden image instinct with spirit" (350).

The spirit which Drowne eventually discovers in himself and communicates to his statue is for Hawthorne a locus of human value. This spirit, however, is not merely a matter of Drowne's subjective consciousness. It is transpersonal, for it is recognized and confirmed by the inhabitants of Boston, who cannot help but respond to its presence in Drowne's statue. And it is objective, by which I mean that it has an ontological existence entirely apart from Drowne. Although Drowne finds the spirit within himself, he also uncovers it within the statue, as though it were preexisting within the wood itself:

It seemed as if the hamadryad of the oak had sheltered herself from the unimaginative world within the heart of her native tree, and that it was only neces- 
sary to remove the strange shapelessness that had incrusted her, and reveal the grace and loveliness of a divinity (351).

The "divinity" within the wood actively intervenes at several points in the story. Hawthorne, for example, describes Drowne's statue in animate terms. Hawthorne notes that, although imperfect in design, attitude, and costume, the statue nevertheless "drew the eye from the wooden cleverness of Drowne's earlier productions and fixed it upon the tantalizing mystery of this new project" (351). The spirit within the statue actually prefigures itself in time, and reveals itself through means other than its physical presence. Although "the image was but vague in its outward presentment; so that, as in the cloud shapes around the western sun, the observer rather felt, or was led to imagine, than really saw what was intended by it," yet it fixes Copley in "speechless astonishment" (353). Although this manifestation of the statue's spirit seems miraculous, it is in fact Hawthorne's attempt to render the reality of a spirit that for him actually exists in the world as a "comprehensive sympathy above us." 15

The objective existence of this spirit colors the entire structure of the story's narrative. The fact that the fan in the hands of the carving and of the actual Portuguese lady break simultaneously, for example, is but a narrative expression of the spiritual coincidence between the lady and her image. In the reality of the spirit everything touches, everything is connected to everything else, and the usual constraints of time and space no longer apply. Harry Levin once said of Reuben Bourne's murder of his son in "Roger Malvin's Burial" that it was "one of those coincidences that seem to lay bare the design of the universe." It would have been more accurate to say that in Hawthorne's universe of meaning, there are no coincidences. Emerson perfectly captured this aspect of the moral reality of Hawthorne's fiction when he remarked that "the perception of real affinities between events (that is to say, of ideal affinities, for those only are real) enables the poet thus to make free with the most imposing forms and phenomena of the world, and to assert the predominance of the soul." 16

Emerson's use of the term "real" is, like Virginia Woolf's, essentially normative. In "Nature," Emerson stops short of an outright idealism. In a similar way, Hawthorne does not deny the reality of Drowne's wooden carvings, of that "strange shapelessness" (351) that surrounds the spirit. Hawthorne's point is only that human value does not inhere in such aspects of reality, and that to collect and communicate moral reality the artist must therefore carve through to the hidden realm of the spirit. Although this realm of the spirit exists objectively, Hawthorne makes

${ }^{15}$ Hawthorne, The House of the Seven Gables, 59.

${ }^{16}$ Levin, The Power of Blackness (New York: Vintage, 1960), 55; Emerson, "Nature," in Nature, Addresses and Lectures (Boston: Houghton, Mifflin, 1903), 54. 
clear that Drowne can discern it in nature only because he has first discovered it within himself. Through the "passionate ardor" (357) of his love, Drowne reaches "the very highest state to which a human spirit can attain" (362); he becomes "consistent with himself" (362). Drowne, in other words, finds that his own "ethereal essence" (351) is matched by an animate spirit in nature; when Drowne becomes fully alive to his own soul, he also becomes capable of perceiving "the hamadryad" within the oak. Conversely, when Drowne loses his "warmth and sensibility" (353), he also reassumes his "mask of dulness" (362), and is left "without the power even of appreciating the work that his own hands had wrought" (362). Nature and character thus mirror each other; Drowne can discern in nature only so much spirit as he has first realized within himself.

In his portrait of Drowne's development, then, Hawthorne describes the conditions under which the moral reality of human value can be known. These conditions are paradoxical, for although moral reality objectively exists, it can only be known through a form of knowledge that is personal and experiential. Note that this form of knowledge entirely bypasses socially authoritative channels of truth. For example, the "well-spring of inward wisdom" that gushes forth from Drowne's heart enables him to sweep aside the formal and socially approved "rules of art" (355) with which he is confronted by Copley. Drowne needs no such social guidance because he has personally experienced the reality of the spirit, and the artistic "rules" of the academy represent at best a secondhand form of knowledge. As Thoreau once said, "I should say that the useful results of science had accumulated, but that there had been no accumulation of knowledge, strictly speaking, for posterity; for knowledge is to be acquired only by a corresponding experience. How can we know what we are told merely?" 17

Thoreau's observation illuminates why Hawthorne characteristically speaks of moral reality as hidden. Merely to be "told" something is to receive information which strikes the outward ear or the intellect, but it is not to assimilate that information into inward patterns of experience. Most men do not assimilate the information they receive; in the ordinary course of their lives they perceive only the external outlines of nature that are necessary for the instrumental activities of the intellect. The inner core of their personality is not touched. This inner core can be engaged only by being brought into contact with a corresponding spirit within nature, a spirit that transcends the external senses. Whenever the realm of spirit manifests itself in "Drowne's Wooden Image," Hawthorne carefully notes how it appears beyond "its outward presentment" (353), and speaks instead directly to its observer's experience. It is not

${ }^{17}$ Thoreau, A Week on the Concord and Merrimack Rivers (1849; rpt. New York: Signet, 1961), 311. 
seen, but is rather "felt" or "imagined" (353) by its viewers. Hawthorne describes how the townspeople sense in Drowne's statue "an indefinable air and expression" (356), and respond with fear because the statue seems "preternatural" (356), and from another "sphere" (356). Drowne's statue is not merely seen; it instead reaches out and touches, and even alters the experiences of those who observe it. The statue, in fact, is a perfect emblem of the living spirit which lies everywhere implicit within nature. Copley immediately discerns this spirit, exclaiming, "Here is the divine, the life-giving touch. What inspired hand is beckoning this wood to arise and live" (353)? And a living statue is precisely what the general population of Boston will later perceive. The legend which is then created and handed down in "the traditionary chimney corners of the New England metropolis" (357), while false to an outward fact, is nevertheless true to an inner spiritual reality. By the end of the story, Boston's inhabitants have come to experience "the predominance of the soul."

Hawthorne's focus on the experiential assimilation of spiritual reality deeply affects the aesthetic characteristics of his story. Notice, for example, Hawthorne's construction of the scene of Copley's first visit to Drowne's studio. We are told that, "in the dearth of professional sympathy" (351), Copley wishes to cultivate Drowne's friendship. On entering the shop, Copley pays Drowne a dubious compliment, which the latter properly rejects. Copley is amazed. "How is it," he asks, "that, possessing the idea which you have now uttered, you should produce only such works as these?"

The carver smiled, but made no reply. Copley turned again to the images, conceiving that the sense of deficiency which Drowne had just expressed, and which is so rare in a merely mechanical character, must surely imply a genius, the tokens of which had heretofore been overlooked. But no; there was not a trace of it. He was about to withdraw when his eye chanced to fall upon a half-developed figure which lay in a corner of the workshop (352-53).

What is fascinating about this scene is Hawthorne's notation that Copley "was about to withdraw": about to withdraw, that is, in utter disregard for the social purposes of his visit, for not only had Copley failed to cultivate Drowne's professional friendship, he had not even offered the common civilities of social conversation. Hawthorne's disrespect for the social forms of his characters' interactions could not be more plain. This disrespect is justified, however, because for Hawthorne moral knowledge was a matter of inward experience, and from that perspective social conversation and amenities could only be regarded as external and shapeless. Thoreau once complained, for example, how "hollow and ineffectual ... is our ordinary conversation. Surface meets surface. When our life ceases 
to be inward and private, conversation degenerates into mere gossip." 18 In the economy of Hawthorne's fiction, there is no room for mere "gossip." Hawthorne is unwilling to permit his characters simply to talk; he will not portray them performing the dance of social formalities. ${ }^{19} \mathrm{He}$ is interested instead in moral reality, and significant interactions between his characters thus occur when their inner experiences touch and engage. One thinks of the "contagion" that overcomes Robin at the conclusion of "My Kinsman, Major Molineux," or of the "continual flow of natural emotion" that, like an "infection," reveals the "wild wishes and childish projects" of the family in "The Ambitious Guest." Apart from such affective exchanges, Hawthorne's characters have virtually no social existence.

Indeed, Hawthorne often deliberately stylizes interactions between his characters that do not seriously engage their experience. For example, when Drowne promises Captain Hunnewell to keep the secret of his figurehead, Hawthorne continues:

Captain Hunnewell then took Drowne by the button, and communicated his wishes in so low a tone that it would be unmannerly to repeat what was evidently intended for the carver's private ear. We shall, therefore, take the opportunity to give the reader a few desirable particulars about Drowne himself (348).

The effect of this narrative transition is to make the reader feel as if he were a member of a theatrical audience witnessing a stage whisper, as if he had received one of those "little slaps at credulity" for which James took Trollope to task. ${ }^{20}$ Hawthorne can intervene in this manner, however, because of his assumption that the credulity of his narrative depends upon his rendition of the reality of his characters' inward experiences rather than upon his portrayal of outward appearances or actions. When Drowne bends over to embrace the statue, for example, the patent theatricality of the gesture is irrelevant to Hawthorne's design; the gesture is merely a conventionalized sign pointing to Drowne's true inner feelings, and has no other fictional purpose. The same conventionalization also characterizes Hawthorne's rendition of dialogue. Copley's theatrical exclamations in the presence of the statue make no attempt to mimic actual speech; they are instead meant only to express his inward experience of

\footnotetext{
${ }^{18}$ Thoreau, "Life Without Principle," in The Portable Thoreau, ed. Carl Bode (New York: Viking, 1964), 654.

${ }^{19}$ Unless, of course, Hawthorne is interested in demonstrating, as in "Feathertop: A Moralized Legend," that his characters exist only in the "completely and consummately artificial" world of "a well-digested conventionalism." See Mosses From an Old Manse, 274-75.

${ }^{20}$ Henry James, The Future of the Novel: Essays on the Art of Fiction, ed. Leon Edel (New York: Vintage, 1956), 247.
} 
Drowne's art. Dialogue thus performs a chiefly expressive function, and this function is compatible with widely various forms of speech, ranging from Copley's measured eloquence, to Captain Ahab's Shakespearean rhetoric in Melville's Moby Dick, to the outright theatrical dialogue of the "Midnight, Forecastle" chapter of that romance.

Another way of looking at this issue is that for Hawthorne action and dialogue are not constitutive of character. Character is instead defined by an orientation to the objective realm of spirit, which is to say by the internal organization of experience. In his description of the relationship between the Portuguese lady and Drowne's statue, Hawthorne illustrates how art can reproduce the experiential organization of its subject:

The face (of the Portuguese lady) with its brilliant depth of complexion had the same piquancy of mirthful mischief that was fixed upon the countenance of the image, but which was here varied and continually shifting, yet always essentially the same, like the sunny gleam upon a bubbling foundation (359).

The "mirthful mischief" of the lady, while affected by the flux of everyday life, nevertheless remains "essentially the same." It is her settled mode of being, and, for Hawthorne, the essence of her character. It is this essence that is captured and presented by Drowne's marvelous art. In a similar manner, the core of Drowne's character for Hawthorne will be the presence or absence of the "sensibility" (362) kindled by his love, and his actions and dialogue will be expressive of this essence. The techniques which Hawthorne uses to represent character, action, and dialogue, in short, are deeply influenced by the moral reality which he is striving to establish. This moral reality, which defines the nineteenth-century American romance, can, in its most general form, be characterized by two principles. First, there exists a concealed reality of spirit which is the locus of human value and meaning. I shall call this spiritual reality the "privileged order," since it is a realm where morality and power coincide and where the usual constraints of time and space do not apply. Second, this privileged order can be known only through a form of knowledge that is personal and experiential. Unlike scientific information, knowledge of the privileged order is not public or transferable through education or training. It involves instead private and immediate forms of discernment, such as intuition, sympathy, imagination, or the emotions. "Without imagination," says Melville in his chapter on the whiteness of the whale, "no man can follow another into these halls." The family of aesthetic characteristics that flows from these two principles is that which we recognize as the nineteenth-century American romance.

These two principles may perhaps best be conceived as assumptions that systematically create an entire field of meaning in which they are 
themselves transcended. The force of this field can persist even if both assumptions are specifically denied. In Pierre, for example, Melville pointedly rejects both assumptions, concluding that the world consists

of nothing but surface stratified on surface. To its axis, the world being nothing but superinduced superficies. By vast pains we mine into the pyramid; by horrible gropings we come to the central room; with joy we espy the sarcophagus; but we lift the lid-and no body is there!- -appallingly vacant as vast is the soul of a man! ${ }^{21}$

For Melville this spiritual vacancy was appalling, leaving him in the grip of an agonizing nihilism. This nihilism, however, was but the negative reflection of his initial assumptions. If Melville had not expected to find an objective moral order revealed within the divinity of the individual soul, he would not have despaired at its absence. His premises defined the conditions of his despair. The field of meaning created by the assumptions of the romance survived in Melville despite his rejection of those assumptions.

After Pierre, it took almost forty painful years before Melville was able to free himself from this field of meaning. In Billy Budd, he eventually composed a novel that could face the "monotonous blank" of nature and yet allow that moral meaning could legitimately be the product of merely human society and institutions. After much struggle, Melville had come to accept what the sociologist Lester Ward, born a generation after Melville, naturally assumed: "Nature is wholly unmoral . . . The prevalent view that ethics is a vast system coextensive with the universe belongs to that class of vainglorious conceptions that make up the anthropocentric philosophy of the prescientific period and of the uninformed generally, and tends, like all crude and vaunting ideas, to render men arrogant and intolerant." The moral universe inhabited by Ward was one in which, as William James put it, "'the words 'good,' 'bad,' and 'obligation' . . . mean no absolute natures, independent of personal support. They are objects of feeling and desire, which have no foothold or anchorage in Being, apart from the existence of actually living minds." ${ }_{22}$

This universe is familiar to us, for it is essentially our own. We find it visible, to use Edwin Cady's felicitous phrase, in "the light of common day." For Cady this light permits the "common vision" upon which "the

${ }^{21}$ Melville, Pierre: Or, the Ambiguities (1852; rpt. Evanston, Ill.: Northwestern Univ. Press, 1971), 285.

${ }^{22}$ Melville, "Billy Budd," in Great Short Works of Herman Melville, ed. Warner Berthoff (1924; rpt. New York: Harper, 1969), 485; Ward, 'Sociology and Psychology,'” The American Journal of Sociology, 1 (1896), 621; James, "The Moral Philosopher and the Moral Life,"' The Will to Believe and Other Essays in Popular Philosophy and Human Immortality (New York: Dover, 1956), 197. 
possibility of literary realism hangs. ${ }^{23}$ Once it is understood, however, that all literature rests upon common vision and that, so to speak, the atmospheric effects evolve in time, the nature of that vision, rather than its mutuality, suddenly becomes problematic. Henry James's "The Real Thing" explores the nature of that vision, investigating in its own intense way the manner in which reality can also be problematic for the realist.

"The Real Thing" is narrated by an artist who, despite ambitions to paint portraits, earns his living doing black and white illustrations for books. An impoverished gentleman and his wife, Major and Mrs. Monarch, importune him to hire them as models for his work on society novels. They are "the real thing" $(57,61)$, by which James's narrator means that they are "essentially and typically smart" (47), "all convention and patent leather" (65). ${ }^{24}$ More from pity than anything else, the artist hires the couple, but very quickly discovers that he cannot draw from them because they are too stiff. His work degenerates and he is forced to fire them. He decides instead to draw his society figures from two "make-believe" (57) models: Miss Churm, a freckled cockney girl, and Oronte, an Italian street-vendor.

The story early on draws a distinction between photography and art. Major and Mrs. Monarch, we are told, have been photographed a great many times, and are excellent photographic subjects. Yet while trying to draw Mrs. Monarch, James's narrator admits:

I could see she had been photographed often, but somehow the very habit that made her good for that purpose unfitted her for mine. . . . After a few times I began to find her too insurmountably stiff; do what I would with it my drawing looked like a photograph or a copy of a photograph. Her figure had no variety of expression-she herself had no sense of variety. You may say that this was my business, was only a question of placing her. I placed her in every conceivable position, but she managed to obliterate their differences. She was always a lady certainly, and into the bargain was always the same lady. She was the real thing, but always the same thing (55-56).

Photographic copies of reality produce results no better than Drowne's mechanical carvings. James thus stands with Hawthorne in support of the position that an artist cannot passively acquiesce in circumstances, but

\footnotetext{
${ }^{23}$ Cady, The Light of Common Day: Realism in American Fiction (Bloomington: Indiana Univ. Press, 1971), 20.

${ }^{24}$ All page references to “The Real Thing”' are from Henry James, Selected Short Stories, ed. Michael Swan (New York: Penguin, 1963).
} 
must actively transform and develop his material. For sentiments such as these, James has often been termed a romancer, but this is to miss his essential inversion of the terms of the romancer's dilemma. For Drowne the task was to penetrate beneath a shapeless outward appearance to a deeper and truer spiritual reality; James's narrator, on the other hand, never denigrates the outward reality of the Monarchs-in fact he stresses it-he only claims that for art adequately to represent precisely this reality, the artist must have a certain freedom. This is because, as James's narrator puts it, "the defect of the real . . . [is] so apt to be a lack of representation" (50).

The supreme virtue of the novel, James tells us, is "the air of reality (solidity of specification)." In part this is a question of aesthetic craft; the illusion of reality cannot be generated by a mere photographic copy of reality. "The novelist who doesn't represent, and represent 'all the time,' is lost." The novel works through "the value of composition." ${ }^{25}$ But this question yields to a more fundamental inquiry: assuming all the required craft, what is the precise nature of the reality which the novel must strive to construct so as to be able to attain its end of meaning? James's rejection of photographic reality is essentially the same as his rejection of Zola's scientific naturalism: he failed to see the moral meaning in it. He could find in it no "pearl of philosophy, of suggestion, or just homely recognition."

Our various senses, sight, smell, sound, taste, are . . . more or less convinced; but when the particular effect upon each of these is added to the effect upon the others the mind still remains bewilderedly unconscious of any use for the total. $^{26}$

A photographic copy of reality, in other words, does not produce the moral reality required by the novel.

James's own particular "use," the hook upon which he preferred to hang his meaning, was "the perfect dependence of the 'moral' sense of a work of art on the amount of felt life concerned in producing it." And "felt life" meant, above all, the consciousness of relation. "The figures in any picture, the agents in any drama, are interesting only in proportion as they feel their respective situations; since the consciousness, on their part, of the complication exhibited forms for us their link of connection with it." 27

${ }^{25}$ James, "The Art of Fiction," in The Future of the Novel, 14; and The Art of the Novel (New York: Scribner's, 1962), 94, 99.

${ }^{26}$ James, "Emile Zola," in Notes on Novelists (New York: C. Scribner's Sons, 1914), 51-52.

${ }^{27}$ James, Art of the Novel, 45, 62. 
The necessity and difficulty of perceiving such consciousness of relation constitutes the inner drama of "The Real Thing." Its narrator is straightforward about his purposes:

I adored variety and range, I cherished human accidents, the illustrative note; I wanted to characterize closely, and the thing in the world I most hated was the danger of being ridden by a type. . . . I held that everything was to be sacrificed sooner than character (56).

When his friends argue with him that type could easily be character, he answers, "Whose? It couldn't be everybody's -it might end in being nobody's" (56). And here the word "type" is not used in the sense in which it is employed by the romance, to signify a physical embodiment of the privileged order, but rather it is meant in its representative sense, in its meaning as the typical. A typical character, for James, is nobody's character. It is a social abstraction, without individuality, without any consciousness of relation.

For James's narrator, however, the Monarchs are precisely a social abstraction. They are for him "essentially and typically smart," "all convention and patent leather." Behind this conventional exterior, the narrator can see nothing but "the blankness, the deep intellectual repose of the twenty years of country-house visiting which had given them pleasant intonations" (49).

James rather broadly hints that his narrator's inability to use the Monarchs as models is at least in part due to his own incapacity to see behind this social facade. And what in contrast makes James's story succeed and saves it from being a rather simple parable on the nature of representation, is its fine final illumination of the depths of pain and humiliation that lie underneath the Monarchs' conventional exterior. When they are fired from their job as models, they return to ask for work as servants. "When it came over me, the latent eloquence of what they were doing, I confess that my drawing was blurred for a moment-the picture swam" (68). Although James is careful not to sentimentalize the situation and to make clear that models are not paid to be reticent, his eloquent revelation of the Monarchs' feelings contrasts sharply with his narrator's need for the assistance of professional models, and highlights his narrator's inability truly to penetrate to the significance of "the real thing."'

The aesthetic strategy which James pursues in presenting this revelation provides an instructive contrast to the romance. In "The Old Apple Dealer," Hawthorne set himself the task of sketching "a character which is . . o of too negative a description to be seized upon and represented to the imaginative vision by word painting." As in the relation of the 
Monarchs to James's narrator, the apple dealer seems to lack the character to sustain art. Hawthorne solves this challenge and endows his subject with moral meaning by placing the peddler within the context of the privileged order. At the climax of the story, Hawthorne is able to justify this apostrophe:

Many would say you have hardly individuality enough to be the object of your own self-love. How, then, can a stranger's eye detect anything in your mind and heart to study and to wonder at? Yet, could I read but a tithe of what is written there, it would be a volume of deeper and more comprehensive import than all that the wisest mortals have given to the world; for the soundless depths of the human soul and of eternity have an opening through your breast. ${ }^{28}$

Hawthorne thus manages to give significance to the apple dealer and to his story by the evocation of an ontologically distinct realm of value. James, on the other hand, gives meaning to the Monarchs and to his story by the technique of widening our field of vision. The suffering of the Monarchs is not of a different order of reality from that which has occurred in the rest of the story. James does not rely on a distinct realm of value to achieve significance, but rather simply lets us more thoroughly understand the consciousness of his subjects. And from this contrast we may deduce the first of our characterizations of the moral reality of American realism: the privileged order has ceased to exist. ${ }^{29}$ Note the consequences of this fact for the narrative organization of these two stories. The effect of the final revelation of "The Old Apple Dealer" is meant to rest on paradox. The more insignificant the peddler, the more unprepared the reader for the final illumination of meaning, the more sharply drawn is the point that the realm of value and "eternity" subsists everywhere. The power and the prevalence of the privileged order is thus underscored by the very contrast between outward appearance and spiritual reality. As Emerson emphasized in his essay on "The Poet," "[t]he meaner the type by which a law is expressed, the more pungent it is, and the more lasting in the memories of men." ${ }^{30}$ Precisely the reverse is true

${ }^{28}$ Hawthorne, "The Old Apple Dealer, Mosses From an Old Manse, 502-03.

${ }^{29}$ This does not imply that realism will not contain supernatural elements, but it does imply that these elements will remain precisely anomalous, the "objective side" of which, as James so accurately understood, "will practically run thin," and the meaning of which must finally be tied to "somebody's normal relation to something." See Art of the Novel, 256. Mark Twain said it more bluntly in his essay on "Fenimore Cooper's Literary Offenses": "The personages of a tale shall confine themselves to possibilities and let miracles alone; or, if they venture a miracle, the author must so plausibly set it forth as to make it look possible and reasonable." Selected Shorter Writing of Mark Twain, ed. Walter Blair (Boston: Houghton Mifflin, 1962), 228.

${ }^{30}$ "The Poet," in Ralph Waldo Emerson: Essays and Journals, ed. Lewis Mumford (Garden City, N.Y.: Doubleday, 1968), 254. 
for James's creation of meaning in the Monarchs: the more unprepared we are for the final illumination of their suffering, the less likely we are to find it significant. This is usually explained by the fact that realism relies for effect upon plausibility. The point to be made, however, is that such plausibility would be meaningless if moral reality were understood to be discontinuous with ordinary experience.

Although the privileged order created a hiatus between outward appearance and spiritual reality, it also functioned, on a deeper level, to unify the world. Nature, society, and character all participated in the privileged order, all shared a common moral essence, and thus could all be known through an identical form of experiential knowledge. With the demise of the privileged order this unity disappeared. Not only did nature, society, and character become separate subjects of knowledge, but they also became the objects of distinct forms of inquiry. Nature began to be understood in the language of science, society in that of manners and decorum, character in that of psychology or, in James's words, "the beautiful circuit and subterfuge of our thought and our desire." It is thus possible to understand James's critique of Zola's naturalism as an indictment of a kind of category mistake - the mistake of applying an analytic of things to human beings-a perspective which must inevitably miss "the human note" and fail in "the perception of character, of the very way that people feel and think and act." 31

The locus of meaning in "The Real Thing" lies in the interplay between two of these ways of understanding the world. The story vibrates between its narrator's perception of the Monarchs as social "types," and his apprehension of the "felt life" that constitutes their character. This is a general characteristic of American nineteenth-century realism, which took as its particular province of meaning "the organic, indissoluble connection between man as a private individual and man as a social being, as a member of a community." "32 For realism moral reality hinged on the delicate interaction between social and personal ways of knowing, between the humanization of convention and the socialization of the individual.

Developing simultaneously with the emergence of the professional social sciences, ${ }^{33}$ American realism, one might say, discovered the social field. This is perhaps its most striking point of departure from the ro-

${ }^{31}$ James, The Art of the Novel, 32; James, The Future of the Novel, 95-96.

${ }^{32}$ Georg Lukacs, Studies in European Realism (New York: Grosset and Dunlap, 1964), 8.

${ }^{33}$ See Thomas L. Haskell, The Emergence of Professional Social Science: The American Social Science Association and the Nineteenth-Century Crisis of Authority (Urbana: Univ. of Illinois Press, 1977). In terms that could easily be applied to the development of realism, Haskell explains the emergence of professional social science as a response to the "growing interdependence among all components of society, individual as well as institutional" (28). 
mance. As we have seen, the romance did not respect the world of social conventions and forms. As Melville said in Mardi, "however desirable as incidental attainments, conventionalities, in themselves, [are] the very least of arbitrary trifles; the knowledge of them innate with no man." ${ }_{34}$ Moral reality for the romance was not a matter of social rules of behavior, but of the privileged order, which, like the "eternity" that opened into the old apple dealer's breast, was perceived to be timeless and unaffected by the vagaries of particular social mores. The privileged order could only be known through personal experience, and this experience was thus conceived as the mirror image of the privileged order. It was understood to be universal and untouched by superficial social characteristics:

For Man, like God, abides the same

Always, through all variety

Of woven garments to the frame..$^{35}$

The literary task of the romance was thus to penetrate through the "garments" to the "frame." It therefore tended to portray significant interactions between characters in ways that transcended particular social forms and directly expressed universal inward experiences. One thinks, for example of the "abounding, affectionate, friendly, loving feeling" described in the "A Squeeze of the Hand" chapter of Moby Dick, or of the "wild, mystical sympathetical feeling" through which Ahab spiritually overpowers his crew. ${ }^{36}$ Both feelings are manifestations of universal human emotions, and both refuse to be confined by any particular social context. The difficulty faced by the romance, however, was that the conventionalities of everyday life continually interfered with such direct expressions of experience. Hawthorne thus complained of the difficulty of writing a romance in America where "actualities" were "so terribly insisted upon."

No author, without a trial, can conceive of the difficulty of writing a romance about a country where there is no shadow, no antiquity, no mystery, no picturesque and gloomy wrong, nor anything but a commonplace prosperity, in broad and simple daylight. . . . It will be very long, I trust, before romance writers may find congenial and easily handled themes . . . in any characteristic and probable events of our individual lives. Romance and poetry, ivy, lichens, and wall-flowers, need ruin to make them grow. ${ }^{37}$

${ }^{34}$ Melville, Mardi: and a Voyage Thither (1849; rpt. Evanston, Ill.: Northwestern Univ. Press, 1970), 246.

${ }^{35}$ Melville, Clarel: A Poem and Pilgrimage in the Holy Land (1876; rpt. New York: Hendricks, 1960), 481.

${ }^{36}$ Melville, Moby Dick: Or, The Whale (1851; rpt. Indianapolis: Bobbs-Merrill, 1964), 532, 239.

${ }^{37}$ Hawthorne, Pref., The Marble Faun (Boston: Houghton, Mifflin, 1888), 15. 
In the "broad and simple daylight" of American prosperity there were no settings in which the social forms of the "characteristic and probable events of our individual lives" could be set aside and universal experience be permitted to flourish.

With the demise of the privileged order the concept of universal human experience lost its preferred moral position. For the realist, human experience was legitimate and important even if it were only the contingent result of particular social customs. Indeed, so great was the accumulated influence of social conventions, that the realist, like the new social scientists, began to view character as inherently socialized. Thus James could remark that "experience is our apprehension and our measure of what happens to us as social creatures." ${ }^{38}$ From this perspective, it was natural for James to stand Hawthorne's complaint about the difficulties of American authorship on its head. "It is on manners, customs, usages, habits, forms, upon all these things matured and established, that a novelist lives," he said in a letter to Howells:

They are the very stuff his work is being made of; and in saying that in the absence of those 'dreary and worn-out paraphernalia' which I enumerate as being wanting in American society, "we have simply the whole of human life left,' you beg (to my sense) the question. I should say we had just so much of it as these same 'paraphernalia' represent, and I think they represent an enormous quantity of it..$^{39}$

Unlike Hawthorne, James sought a richer social texture, one that would enable him to communicate that much more "felt life."

Since for the realist experience was in large measure constituted by social conventions, characters in realist fiction must be regarded as the products of the social worlds they inhabit. The moral reality of the realist novel thus depends in part on the historical fidelity with which these worlds are reproduced. In contrast to the romance, therefore, dialogue in the realist novel is rendered in historically accurate dialect, while the speech of characters mimics socially accurate patterns of expression. Sometimes the representation of social texture achieves the density of anthropological description. Notice, for example, how James's narrator in "The Real Thing" describes an entrance of the Monarchs:

[T]hey came in, the Major and his wife, with their society laugh about nothing (there was less and less to laugh at), like country-callers-they always reminded me of that - who have walked across the park after church and are presently persuaded to stay to luncheon (65).

${ }^{38}$ James, The Art of the Novel, 64-65.

${ }^{39}$ The Letters of Henry James, ed. Percy Lubbock (London: Scribner's, 1920), I, 72-73. 
The meaning of this passage finally rests on the accuracy of its social observation, but its allusions are so historically specific that they are momentarily opaque to the modern reader. Whether country callers expected to be "persuaded" to stay to luncheon, for example, will tell the reader much about both the entrance of the Monarchs and the tradition of country calling. The reader, in other words, must be educated to understand the social customs that give meaning to behavior. But in this the reader is in no different situation than James's characters. In "Daisy Miller," for example, Winterbourne, trying to interpret Daisy's conduct, becomes "vexed at his want of instinctive certitude as to how far her eccentricities were generic, national, and how far they were personal," (185). ${ }^{40}$ Having "lived too long in foreign parts" (192), Winterbourne is unfamiliar with American social customs, and so unable accurately to assess the significance of Daisy's behavior.

Winterbourne can, of course, acquire information about American social practices; he can learn the social language that fixes and gives meaning to Daisy's behavior. In realism, therefore, unlike in the romance, the exercise of moral judgment depends upon a form of knowledge that is public and transmissible. The understanding of moral reality increases as this knowledge becomes more comprehensive. As Winterbourne learns more about Daisy's conduct and social context, he is able to evaluate her character with more assurance. In this sense action in the realist novel is constitutive of character, in contrast to the romance, in which action is expressive of character. Winterbourne's inquiry, for example, may be profitably compared to that of Coverdale in The Blithedale Romance. Coverdale's knowledge of Zenobia's lack of virginity does not derive from his perception of her actions or her social circumstances. It is instead a personal and immediate impression, a direct intuition "unauthorized by any circumstance or suggestion that had made its way to my ears." ${ }^{41}$ Like Coverdale, the reader of the romance is given direct access to the "ethereal essence" of the romance's characters, and the task of the romancer is to demonstrate how the essence of a character radiates through his actions, speech, gestures, clothing, and other accoutrements. The task of the realist, on the other hand, is to constitute his characters through the presentation of successive layers of information. The reader must then construct and evaluate the novel's characters on the basis of the information provided him, just as Winterbourne must attempt to grasp the character of Daisy. In this process realism assumes a certain degree of cultural education among its readers. Thus, while the romancer wrote for "the

\footnotetext{
${ }^{40}$ All references to "Daisy Miller" are from Henry James, Selected Short Stories, ed. Michael Swan (New York: Penguin, 1963).

${ }^{41}$ Nathaniel Hawthorne, The Blithedale Romance (Boston: Houghton, Mifflin, 1883), 372.
} 
mighty heart" ${ }^{42}$ of the world, the realist wrote for those with "taste." "Don't pretend . . . to have pretty illusions about the public," says Jack Hawley, a critical friend of James's narrator in "The Real Thing." "It's not for such animals you work-it's for those who know, coloro che sanno", (64). ${ }^{43}$

In "Daisy Miller" Winterbourne eventually learns that Daisy's conduct cannot be adequately encompassed by any code of social usage. She is "completely uncultivated"'(149) and "very ignorant"(162). But Daisy is also imbued with an intensity of life which no education can produce. James is of two minds about this intensity. On the one hand, he considers it to be dangerous, leading Daisy recklessly to her death in the malariainfested Roman Colosseum. It is "unreasoning" (171) and "inscrutable" (184), without communicable moral shape or form. On the other hand, it is, as the springtime flower of her name indicates, a vital source of liferenewing energy. Winterbourne, who cannot respond to this energy, remains at the conclusion of the novel imprisoned by the forms of social propriety and as personally lifeless as his name suggests. This tension within Daisy Miller exposes the underlying moral paradox of realism, for if the self is social, what is the individual? Just as the romance is the locus of a struggle between spiritual reality and outward appearance, so the realist novel is the scene of a constant struggle between society and character. Individuals are social, they can only be adequately understood through "manners, customs, usages, habits, forms"; yet, as Daisy Miller or the Monarchs make clear, they are not just social. Social conventions are given by society, yet they must be inhabited by individuals, with their personal feelings and desires.

This moral paradox causes realist fiction to be filled with flickering back and forth between social and psychological perspectives. This doubleness is not, as it is sometimes characterized, a dialectic between appearance and reality ${ }^{44}$ but a competition between two ways of understanding the same events, neither of which can exist without the other. Social standards and conventions give shape and form to the energies of the self, while these energies in turn animate and give meaning to social usages. It is in this mutual dependence of the social and the psychological that the realist novel finds its domain of moral significance. The mistake of the narrator of "The Real Thing" is in viewing the Monarchs only as social conventions. On the other hand, we are not moved at the conclusion of the story

\footnotetext{
42 Melville, Mardi, 600.

${ }^{43}$ At the same time, however, the realist novel was more comfortable than the romance in "educating" its audience to problems of social or political concern.

${ }^{44}$ See, for example, Marius Bewley, The Complex Fate: Hawthorne, Henry James, and Some Other American Writers (London: Chatto and Windus, 1952), 79-114.
} 
merely because we are shown the humiliation of the Monarchs-if by that is meant a psychological state abstracted from social significance. We are moved rather because their suffering is embodied within the "eloquence" of a social gesture, in their offer to become the narrator's servants. The gesture both defines and reveals their pain to the narrator and ourselves.

Richard Rorty has recently and forcefully observed that "' objective truth' is no more and no less than the best idea we currently have to explain what is going on." The concept of moral reality requires us seriously to confront the fact that in the past the "objective" world of human meaning has differed in fundamental ways from our own. The romancer inhabited a world in which, as Melville put it in White-Jacket, the earth was "a fast-sailing, never-sinking world-frigate, of which God was the shipwright," and whose "final haven was predestinated ere we slipped from the stocks at Creation." It was a world in which "we ourselves are the repositories of the secret packet" that would dispel the mysteries of the voyage. We recognize the aesthetic consequences that flow from the attempt to represent such a world in fiction as the genre of the romance. The genre of the realist novel, on the other hand, is the aesthetic result of the attempt to represent in fiction a world in which value has no distinct ontological status, and in which human meaning is perceived to reside in the unending and indissoluble tension between self and society ${ }^{45}$

To understand the problem of genre in this fashion thus not only permits the aesthetic attributes of a genre to be systematically identified and explained, but also permits these attributes to be related in a coherent manner to the circumstances of cultural and intellectual history.

${ }^{45}$ Rorty, Philosophy and the Mirror of Nature (Princeton: Princeton Univ. Press, 1980), 385; Melville, White-Jacket; Or, The World in a Man-of-War (1850; rpt. Evanston, Ill.: Northwestern Univ. Press, 1970), 398-99. 